\title{
CAR T-cell therapy in mature lymphoid malignancies: clinical opportunities and challenges
}

\author{
Mayur Narkhede ${ }^{1}$, Amitkumar Mehta ${ }^{1}$, Stephen M. Ansell ${ }^{2}$, Gaurav Goyal ${ }^{1} \wedge$ \\ ${ }^{1}$ Division of Hematology-Oncology, University of Alabama at Birmingham, Birmingham, AL, USA; ${ }^{2}$ Division of Hematology, Mayo Clinic, \\ Rochester, MN, USA \\ Contributions: (I) Conception and design: G Goyal, M Narkhede; (II) Administrative support: None; (III) Provision of study material or patients: \\ None; (IV) Collection and assembly of data: M Narkhede; (V) Data analysis and interpretation: G Goyal, M Narkhede; (VI) Manuscript writing: All \\ authors; (VII) Final approval of manuscript: All authors. \\ Correspondence to: Gaurav Goyal. Division of Hematology-Oncology, University of Alabama at Birmingham, 1802 6th Avenue South Suite 2555 NP, \\ Birmingham, AL 35294, USA. Email: ggoyal@uabmc.edu.
}

\begin{abstract}
The advent of chimeric antigen receptor T-cell (CAR T-cell) therapy has revolutionized the treatment paradigm of various hematologic malignancies. Ever since its first approval for treatment of acute lymphoblastic leukemia (ALL) in 2017, CAR T-cell therapy has been found to be efficacious in various other lymphoid malignancies, with recent approvals in diffuse large B-cell lymphoma (DLBCL) and mantle cell lymphoma (MCL). Although CAR T-cell therapeutics offer a novel immunotherapeutic approach to treat otherwise refractory malignancies, the plethora of studies/products and complexities in manufacturing and administration have led to several challenges for clinicians and the healthcare system as a whole. Some of the areas of unmet need include manufacturing delays, short persistence of CAR T-cells in circulation, lack of predictive biomarkers for efficacy and toxicity, and high cost of therapy. In this review, we evaluate the existing data on the efficacy and safety of CAR T-cell therapies in mature lymphoid malignancies [lymphomas, chronic lymphocytic leukemia (CLL), and multiple myeloma]. We also provide an in-depth review of the challenges posed by CAR T-cell therapeutics and potential strategies to overcome them. With newer CAR T-cell products and incorporation of measures to mitigate toxicities pertaining to cytokine release and neurological syndromes, there is a potential to overcome several of these challenges in the near future. Finally, as CAR T-cell therapy gains regulatory approval for more indications, there is a need to tackle the financial toxicity posed by this modality to sustain patient access.
\end{abstract}

Keywords: Lymphoma; myeloma; cost; toxicities; Hodgkin; mantle; chronic lymphocytic leukemia (CLL)

Submitted Jul 27, 2020. Accepted for publication Dec 23, 2020.

doi: $10.21037 /$ atm-20-5546

View this article at: http://dx.doi.org/10.21037/atm-20-5546

\section{Introduction}

Although numerous advances have been made in harnessing the immune system to specifically target tumor cells, none have possibly been as promising and exciting as chimeric antigen receptor T-cell (CAR T-cell) therapy. CAR T-cells are genetically engineered T-cells consisting of a synthetic tumor antigen recognizing T-cell receptor (TCR) with the ability to mount a T-cell mediated antitumor effect (1-3).

The existing CAR T-cell constructs consist of three components; antigen recognition receptor, a hinged transmembrane domain, and an intracellular signal-

\footnotetext{
^ ORCID: 0000-0001-6148-5177.
} 


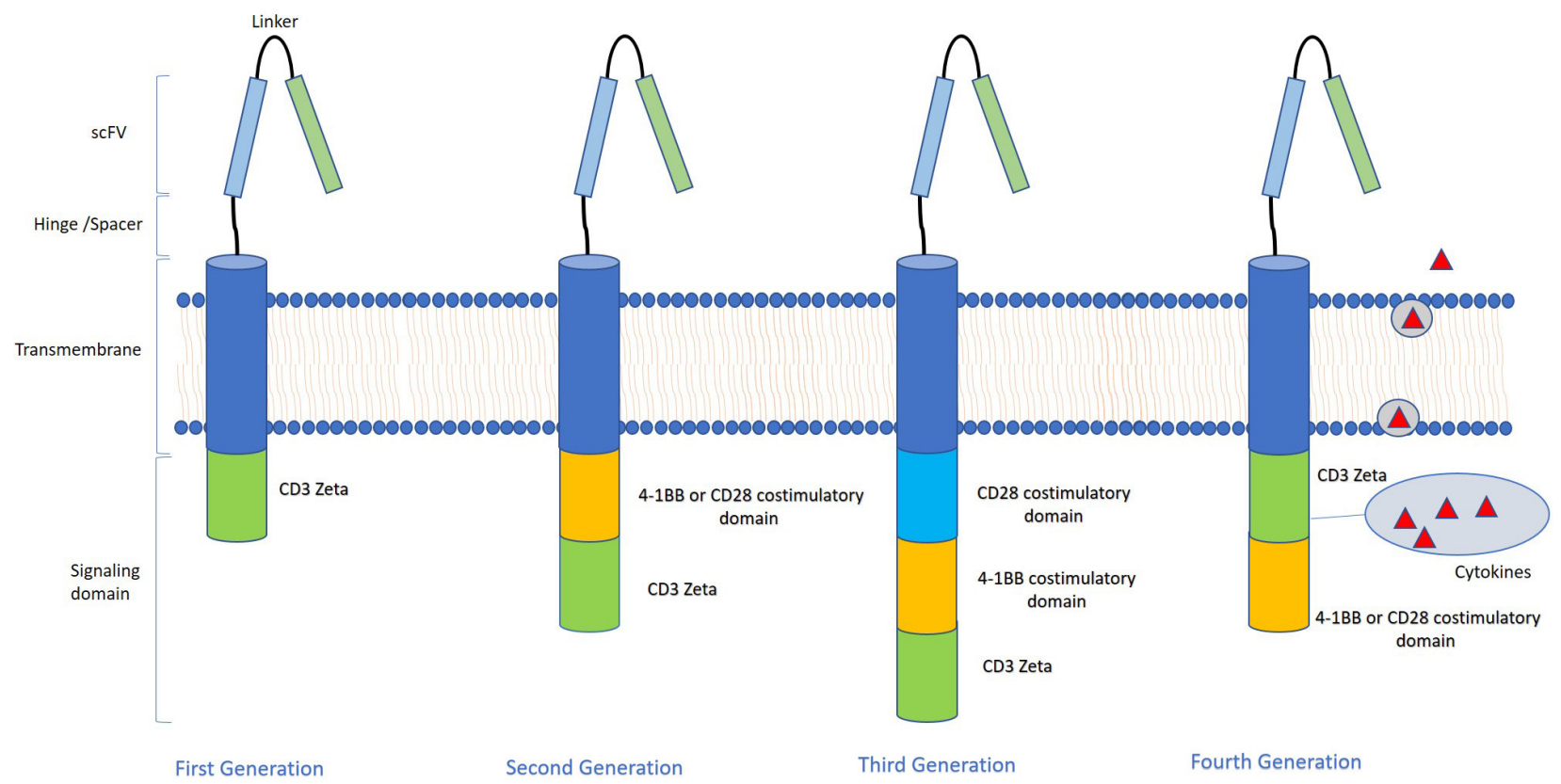

Figure 1 Schematic representation of various CAR T-cell constructs. First generation CAR T-cell consists of an antigen recognition receptor composed of a single-chain variable fragment $(\mathrm{scFv})$ consisting of heavy and light chains of a monoclonal antibody directed against an antigen. The scFv is linked to an intracellular signal-transducing domain by a hinged transmembrane domain. The hinged domain consists of sequences derived from IgG4 and CD8 domains. The intracellular domain contains the cytoplasmic tail of CD3-zeta (CD3 chain), functioning as a signal-transducing domain. The first generation CAR T-cell contains a single transducing domain, CD3. Second generation CAR T-cell constructs, in addition to the signal transducing domain, contains a co-stimulatory domain consisting of either 4-1BB or CD28. Third generation construct has both CD28 and 4-1BB co-stimulatory domains in addition to CD3. The fourth generation CAR T-cell constructs are engineered to release a transgenic cytokine upon CAR signaling in the targeted tumor tissue.

transducing domain (Figure 1). The antigen recognition receptor is composed of a single-chain variable fragment $(\mathrm{scFv})$ consisting of heavy and light chains of a monoclonal antibody directed against an antigen. The $\mathrm{scFv}$ is derived from mouse immunoglobulins. The $\mathrm{scFv}_{\mathrm{v}}$ is linked to an intracellular signal-transducing domain by a hinged transmembrane domain. This hinged transmembrane domain serves as a spacer, which increases the distance of the $\mathrm{scFv}$ from the plasma membrane and is essential for efficient antigen binding and signal induction (4). The intracellular domain contains the cytoplasmic tail of CD3zeta (CD3 $\zeta$ chain), functioning as a signal-transducing domain.

The second generation of CAR T-cells contained additional costimulatory molecules such as CD28, CD137/4-1BB, ICOS, or OX40.

Since the first iteration of CARs, newer methods in molecular biology have led to the construction of more effective second generation CARs, leading to regulatory approvals in lymphoid malignancies including acute lymphoblastic leukemia (ALL), diffuse large B-cell lymphoma (DLBCL) and mantle cell lymphoma (MCL).

Mature lymphoid neoplasms are a heterogeneous group of disorders, ranging from indolent to aggressive lymphomas. They also include multiple myeloma, which is a neoplasm of terminally differentiated B-cells. Although the survival of various B-cell lymphomas has improved after introduction of rituximab-based immunochemotherapy, numerous areas of unmet need persist. In the most common subtype of aggressive lymphomas, DLBCL, the median overall survival for primary refractory disease is about 6 months (5). However, poor prognosis has also been reported among other B-cell lymphomas and multiple myeloma, especially in the setting of primary refractory disease, early relapse, or relapse after multiple lines of therapy (6-8). Although the use of immunotherapy by utilizing immune checkpoint inhibitors has been revolutionary in various malignancies, the response rates 
in lymphoid neoplasms beyond classic Hodgkin lymphoma (HL) have been low. Harnessing of host immunity by utilizing CAR T-cell therapy offers a novel and rational treatment approach to target this patient population. In this review, we focus on the existing data using CAR T-cell therapy in mature lymphoid neoplasms, associated challenges, and potential strategies to overcome them.

\section{CAR-T cells in clinics}

\section{Early clinical development of CAR-T cells}

With successes in preclinical studies, first in human trials were initially conducted in solid tumors targeting diasialoganglioside GD2 in neuroblastoma, $\alpha$-folate receptor (FR) in ovarian cancer, and carboxy-anhydrase-IX (CAIX) antigen in renal cell carcinoma (9-11). These firstgeneration CAR T-cell constructs did not persist in large numbers for the long-term, leading to short term responses. Also, toxicities were observed due to the sharing of antigens on tumor cells and healthy cells, as seen with the antiCAIX CAR T-cell construct with the sharing of the CAIX antigen between renal cell carcinoma cells and normal bile duct epithelium (11). Successful clinical use of CAR T-cells required a targetable antigen overexpressed on tumor cells with minimal off-target effects and a costimulatory domain necessary for persistence of CAR T-cells.

\section{CAR-T cells in non-Hodgkin lymphoma (NHL)}

CD19 is a transmembrane protein with its expression specific to the B-cell lineage of lymphocytes. It is present from the early stages of pre-B-cell development until terminal differentiation into plasma cells (12). Being a B-cell lineage surface marker, CD19 is expressed on the majority of NHL, ALL and chronic lymphocytic leukemia (CLL) cells (13). The most notable clinical use of CAR T-cell therapy has been in B-cell malignancies. Carl June and his colleagues designed an anti CD19 CAR T-cell coupled with 4-1BB (a costimulatory receptor in T cells ) and CD3zeta (a signal-transduction component of the T-cell antigen receptor) signaling domains (14). This second-generation anti CD19 CAR T-cell was infused in patients with CD19 expressing refractory CLL. The CAR T-cells expanded 1,000 times the initial concentration, tracked to the bone marrow and lymph nodes, and achieved deep and durable responses lasting up to 4 years (15). Similarly, CAR T-cells were also studied in other CD19+ NHLs.
Axicabtagene ciloleucel (axi-cel), tisagenlecleucel (tisacel), and lisocabtagene maraleucel (liso-cel) are the three different CAR T-cell therapies studied in relapsed and refractory DLBCL with impressive ORR rates and durable responses (Table 1). Axi-cel and Tisa-cel are US Food and Drug Administration (FDA) approved for the treatment of DLBCL in second or later relapses. Recently, FDA has also approved brexucabtagene autoleucel (also known as KTE-X19) for relapsed/refractory MCL based on impressive ORR rates and durable responses (Table 1).

CD19-CAR T-cell therapy has also been evaluated in CLL and follicular lymphoma and are awaiting approval from the FDA for its use in these indications (Table 2) (1522). CD20 is another well-known target for B-cell NHLs, with some responses noted in initial studies (23). More recently, tandem bispecific anti-CD20, anti-CD19 CAR T-cells have been evaluated for B-cell NHLs with $82 \%$ ORR and comparable safety to other products (24).

\section{CAR T-cell therapy in HL and T-cell lymphoma}

Classic HL and anaplastic large T-cell lymphoma (ALCL) are characterized by overexpression of CD30 protein on the surface of malignant cells. There is limited expression of CD30 on normal cells (25). Brentuximab vedotin, is a drug-antibody conjugate which targets CD30 and has been approved by the FDA for the treatment of HL and ALCL (26). Therefore, CAR T-cells targeting CD30 were developed and studied in HL and ALCL. Compared to the encouraging results seen in B-cell ALL and DLBCL, there is little to report on the efficacy and safety of anti-CD30 CAR-T cell therapy (Table 3) (27-30). The immunosuppressive tumor microenvironment possibly leads to suboptimal responses in HL. Therefore, a clinical trial evaluating the use of PD1 inhibitors after CD30 CAR T-cell is ongoing (NCT04134325). The use of CAR T-cells in HL is still in its infancy and will need better CAR constructs or combination therapy for its successful use in the clinic.

T-cell lymphomas are a heterogeneous group of malignancies of the T-cell origin. The following challenges have made it difficult for utilizing the benefits of CAR T-cell therapy in T-cell lymphomas. With the sharing of the antigens between malignant T-cells and CAR T-cells, concerns of fratricide arise. B-cell aplasia, which is seen after CD19 CAR T-cell therapy, is a common ontarget/off tumor effect observed which requires longterm immunoglobulin infusions. Similar T-cell aplasia, if observed, can lead to severe immunodeficiency with 
Table 1 Phase 2 clinical trials of CAR T-cell therapy in DLBCL, mantle cell lymphoma and follicular lymphoma

\begin{tabular}{|c|c|c|c|c|c|}
\hline Characteristics & $\begin{array}{l}\text { Axicabtagene } \\
\text { Ciloleulcel (16) }\end{array}$ & Tisagenlecleucel (17) & $\begin{array}{l}\text { Lisocabtagene } \\
\text { Maraleucel (18) }\end{array}$ & $\begin{array}{l}\text { Brexucabtage } \\
\text { Autoleucel (19) }\end{array}$ & $\begin{array}{l}\text { Axicabtagene } \\
\text { Ciloleulcel (20) }\end{array}$ \\
\hline Trial & ZUMA-1 & JULIET & TRANSCEND-001 & ZUMA-2 & ZUMA-5 \\
\hline FDA approved indication & Yes & Yes & No & Yes & No \\
\hline $\begin{array}{l}\text { Number of patients } \\
\text { enrolled }\end{array}$ & $\begin{array}{l}111 \text { (101 pts } \\
\text { infused) }\end{array}$ & 111 (93 pts infused) & 342 (268 pts infused) & 74 (68 pts infused) & 140 \\
\hline Co-stimulatory domain & CD28 & $4-1 B B$ & 4-1BB & CD28 & CD28 \\
\hline Cell population & PMBC & PMBC & CD4+ and CD8+ T cells & $\begin{array}{l}\text { PMBC without } \\
\text { CD19+ cells }\end{array}$ & PMBC \\
\hline Conditioning regimen & Cy/Flu & $\begin{array}{c}\text { 73\% Cy/Flu, 20\% } \\
\text { Bendamustine }\end{array}$ & Cy/Flu & Cy/Flu & Cy/Flu \\
\hline $\begin{array}{l}\text { Median time from } \\
\text { apharesis to CAR-T }\end{array}$ & 17 days & 54 days & $\begin{array}{l}24 \text { days (Optimized } \\
\text { subset) }\end{array}$ & 16 days & NA \\
\hline Best ORR & $82 \%$ (CR 58\%) & $52 \%$ (CR 40\%) & 73\% (CR 53\%) & 93\% (CR 67\%) & $\begin{array}{c}\text { 93\% (CR 80\%); FL: } \\
\text { 95\% (CR 81\%); } \\
\text { MZL: } 81 \% \text { (CR 75\%) }\end{array}$ \\
\hline Responses on follow up & $\begin{array}{c}42 \%(\mathrm{CR} 40 \%) \text { at } \\
12 \mathrm{mts}\end{array}$ & $\begin{array}{c}34 \%(\text { CR } 29 \%) \text { at } 12 \\
\text { mts }\end{array}$ & $47 \%$ (CR $41 \%$ ) at $6 \mathrm{mts}$ & $57 \%$ ORR at $12 \mathrm{mts}$ & $68 \%$ ORR at $15 \mathrm{mts}$ \\
\hline $\begin{array}{l}\text { Neurotoxicity, grade } 3 \text { or } \\
\text { higher, \% }\end{array}$ & $28 \%$ & $12 \%$ & $10 \%$ & $31 \%$ & $19 \%$ \\
\hline
\end{tabular}

mPFS, median progression-free survival; CR, complete response; ORR, overall response rate; mDOR, median duration of response; OS, overall survival; mts, months; PMBC, peripheral blood mononuclear cells; CRS, cytokine release syndrome; pts, patients; FL, follicular lymphoma; MZL, Marginal zone lymphoma; tFL, transformed follicular lymphoma; Cy/Flu, cyclophosphamide and fludarabine.

increased incidence of severe opportunistic infections. Also, CAR transduction of malignant cells during autologous generation of CAR T-cells can lead to rapid progression of T-cell lymphoma/leukemia. To overcome these barriers, CAR cells that target unique antigens need to be developed. CAR T-cells targeting CD7 and TCR beta constant 1 are currently being studied in early phase trials (NCT04004637, NCT03590574). Alternatively, CAR NK cells targeting CD5 are also being studied in early phase clinical trials

\section{(NCT03081910).}

\section{CAR T-cell therapy in multiple myeloma}

Despite the development of numerous novel agents in the past couple of decades in multiple myeloma, it remains an incurable disease. The plasma cells lack the expression of CD19, but have an overexpression of B-cell maturation antigen (BCMA). Although BCMA 
Table 2 Early phase clinical trials of CAR T-cell in chronic lymphocytic leukemia

\begin{tabular}{|c|c|c|c|}
\hline Characteristics & Tisagenlecleucel (15) & Lisocabtagene Maraleucel (21) & CTL119 + Ibrutinib (22) \\
\hline scFv origin & Murine & Murine & Humanized \\
\hline Number of patients & 14 & 23 & 20 \\
\hline Best ORR as per iwCLL & $57 \%$ (8 out of 14 ) & $82 \%$ (18 of 22$)$ & $\begin{array}{l}\text { At } 3 \text { months } \\
\text { - } 71 \%(10 \text { of } 14)\end{array}$ \\
\hline uMRD (at any time) & N/A & $\begin{array}{l}\text { Blood: } 15 \text { of } 22 \text { (flow cytometry); BM: } 13 \text { of } 22 \\
\text { (NGS) }\end{array}$ & $\begin{array}{l}\text { At } 3 \text { months in BM } \\
\text { - } 15 \text { of } 18 \text { (flow cytometry) } \\
\text { - } 14 \text { of } 18 \text { (NGS) }\end{array}$ \\
\hline
\end{tabular}

CR, complete response; ORR, overall response rate; OS, overall survival; iwCLL, international working group on chronic lymphocytic leukemia; UMRD, undetectable minimal residual disease; CRS, cytokine release syndrome; scFv, single-chain variable fragment.

is implicated in all stages of differentiation of B-cells, it is of particular interest in multiple myeloma. CAR T-cells targeting BCMA have been successful in phase 2 clinical trials with durable responses (31-34) (Table 4). A biologics license application has been sent to the FDA for the use of idecabtagene vicleucel (ide-cel) in patients with multiple myeloma who have received at least 3 prior lines of therapy including an immunomodulatory agent, a proteasome inhibitor, and an anti-CD38 antibody. Other well-known plasma cell markers are CD138 and CD38. However, they are not specific to plasma cells and raises the concern for safety with utilization of these markers as targets for CAR T-cell therapy. In a study of five patients using CD138-CAR T-cell therapy, no excess toxicities were seen (35). Further studies evaluating these and other targets are underway.

\section{Current challenges in CAR T-cell therapy}

\section{Time from collection to infusion of CAR T-cells}

The time from apheresis to CAR T-cell infusion ranges between 17 to 54 days depending on the manufacturing process of each product. Some patients may experience significant disease progression during this hiatus, necessitating administration of "bridging" therapy. In a
US lymphoma CAR T-cell consortium study, patients who received bridging therapy before CAR T-cell infusion had a low response rate and higher adverse events than those who did not (36). These low response rates could be either due to aggressive underlying disease biology or due to the toxic effects of bridging therapy on CAR T-cells that are subsequently infused. Nonetheless, prolonged turnaround time limits the number of patients who can benefit from CAR T-cell therapy. There is a need to optimize the production process and reduce the manufacturing time (Figure 2). One method to reduce manufacturing time includes the development of allogeneic CAR T-cells or "offthe-shelf" CAR T-cells.

\section{What are allogeneic CAR T-cells or "off-the- shelf" CAR T-cells, and how can they shorten the manufacturing time?}

Since each CAR T-cell product is manufactured for an individual patient, it cannot be reused for other patients. It leads to an increase in cost, labor, and the time required to manufacture them. A possible solution is the development of allogenic or "off-the-shelf" CAR T-cells, which can be used simultaneously for multiple patients. However, there are two significant concerns with the use of allogeneic CAR T-cells in its current iteration; life-threatening graftversus-host disease (GVHD) and CAR T-cell rejection. 
Table 3 CAR T-cell in CD30 positive lymphomas

\begin{tabular}{|c|c|c|c|c|}
\hline Characteristics & $\begin{array}{l}\text { Wang et al. anti-CD30 } \\
\text { CAR therapy (27) }\end{array}$ & $\begin{array}{c}\text { Wang et al. anti-CD30 CAR } \\
\text { therapy (28) }\end{array}$ & $\begin{array}{c}\text { Ramos et al. anti-CD30 CAR } \\
\text { T-cell therapy (RELY-30 trial) (29) }\end{array}$ & $\begin{array}{c}\text { Ramos et al. anti-CD30 CAR } \\
\text { T-cell therapy (30) }\end{array}$ \\
\hline Disease & $\mathrm{HL}$ & $\mathrm{HL}$ and $\mathrm{ALCL}$ & HL & $\mathrm{HL}$ and $\mathrm{ALCL}$ \\
\hline scFV origin & Murine & Murine & Murine & Murine \\
\hline $\begin{array}{l}\text { Number of } \\
\text { patients }\end{array}$ & 18 & 9 & 23 & 9 \\
\hline Best ORR & $38 \%$ (7 of 18$)$ & $77 \%$ (7 of 9$)$ & $66 \%$ (8 of 12$)$ & $33 \% \%$ (3 of 9 ) \\
\hline CR rate & 0 & $77 \%$ (7 of 9$)$ & $58 \%$ (7 of 12$)$ & $33 \%$ (3 of 9$)$ \\
\hline
\end{tabular}

CR, complete response; ORR, overall response rate; CRS, cytokine release syndrome; scFv, single-chain variable fragment; HL, Hodgkin lymphoma; ALCL, anaplastic large cell lymphoma.

Both effects are due to the TCR in $\alpha \beta$ T-cells, which recognize the peptides presented by MHC molecules, differentiating self-antigens from foreign antigens. One approach on developing allogeneic or "off-the-shelf" CAR T-cells is the use of non- $\alpha \beta$ cells such as natural killer (NK) cells engineered with a CAR directed against the tumor antigen. Such CAR-transduced NK cells have successfully been developed from cord blood cells in CD19-positive lymphoid tumors (37). Another approach is the development of CAR T-cells with the deletion of the $\alpha \beta$ TCR gene bypassing the MHC mismatch responses $(38,39)$. ALLO-501 is one such anti-CD19 CAR $\mathrm{T}$ cell product in which the TCR alpha constant gene is disrupted to reduce the risk of GVHD and the CD52 gene is disrupted to permit the use of ALLO-647, an anti-CD52 monoclonal antibody for prolonged host lymphodepletion (40). ALLO-501 in combination with ALLO-647 has shown promise in early phase studies in relapsed DLBCL and FL. Such allogeneic CAR T-cells with deleted TCR genes, however, pose unique problems, such as the need for alternative techniques for expansion of CAR T-cells and their lack of in-vivo persistence after infusion. These issues will need to be addressed before its use in clinical practice. There are multiple ongoing trials with preliminary safety and efficacy results using allogenic CAR T-cells (Table 5).

\section{Durability of responses after CAR T-cell therapy}

The best ORR observed with CAR-T cell therapy for DLBCL ranges between $50 \%$ to $80 \%$ (Table 1). However, most of these responses taper off over a few months, with up to half of the responders relapsing on long-term follow-up. CAR T-cell antigen positive relapses observed after CAR T-cell therapy have been attributed to the lack of T-cell expansion after infusion, lack of persistence of CAR-T cells, and CAR-T cell anergy. Different CAR T-cell constructs used in different clinical trials prevent direct comparisons of efficacy, however, correlative studies suggest T-cell expansion and persistence after infusion is critical for achieving an effective clearance of the cancer (41). The fate of CAR T-cells after infusion is dependent on several factors related to CAR T-cell construct such as type of costimulatory molecules used, type of CAR antibody used, the T-cell phenotype used for manufacturing of CAR T-cells and the expression of T-cell exhaustion markers by the tumor cells leading to T-cell anergy.

How can we improve T-cell expansion and persistence? CD28 co-stimulation is required for clonal expansion of activated $\mathrm{T}$ cells and form effector memory T-cells, whereas the 4-1BB co-stimulation is associated with long-term survival of $T$ cells (42). In preclinical studies, the presence 
Table 4 Phase 2 trials of anti-BCMA CAR T-cell therapy in multiple myeloma

\begin{tabular}{|c|c|c|c|c|}
\hline Characteristics & $\begin{array}{c}\text { Orvacabtagene Autoleucel } \\
\text { (32) }\end{array}$ & $\begin{array}{c}\text { Idecabtagene Vicleucel } \\
\text { (33) }\end{array}$ & JNJ-4528 (31) & LCAR-B38M (34) \\
\hline Trial & EVOLVE & KarMMa & CARTITUDE-1 & LEGEND-2 \\
\hline Patients studied & $\begin{array}{l}\text { MM relapsed to more than } \\
3 \text { lines of therapy* }\end{array}$ & $\begin{array}{l}\text { MM relapsed to more } \\
\text { than } 3 \text { lines of therapy* }\end{array}$ & $\begin{array}{l}\text { MM relapsed to more than } \\
3 \text { lines of therapy }\end{array}$ & $\begin{array}{c}\text { MM relapsed to more than } 3 \text { lines } \\
\text { of therapy* }\end{array}$ \\
\hline $\begin{array}{l}\text { Conditioning } \\
\text { regimen }\end{array}$ & Cy/Flu & Cy/Flu & Cy/Flu & Cy alone \\
\hline $\begin{array}{l}\text { Responses at recent } \\
\text { update }\end{array}$ & $\begin{array}{l}\text { At all dose levels } \\
\text { - ORR: } 40 / 44(91 \%) \\
\text { - sCR + CR: } 17 / 44(39 \%) \\
\text { - VGPR: } 11 / 44(25 \%) \\
\text { - PR: } 12 / 44(27 \%)\end{array}$ & $\begin{array}{l}\text { At all dose levels } \\
\text { - ORR: } 94 / 128(73 \%) \\
\text { - sCR: } 40 / 128(31 \%)\end{array}$ & $\begin{array}{l}\text { At all dose levels } \\
\text { - ORR: } 29 / 29(100 \%) \\
\text { - sCR: } 22 / 29(76 \%) \\
\text { - VGPR: } 6 / 29(21 \%) \\
\text { - PR: } 1 / 29(3 \%)\end{array}$ & $\begin{array}{l}\text { At all dose levels } \\
\text { - ORR: } 50 / 57(88 \%) \\
\text { - sCR: } 42 / 57(74 \%) \\
\text { - VGPR: } 2 / 57(4 \%) \\
\text { - PR: } 6 / 57(11 \%)\end{array}$ \\
\hline Long-term follow-up & $\begin{array}{l}\text { mPFS not reached after } \\
5.9 \text { mts of median follow- } \\
\text { up }\end{array}$ & $\begin{array}{c}\text { mPFS of } 8.6 \mathrm{mts} ; \mathrm{mDOR} \\
\text { pf } 10.6 \mathrm{mts}\end{array}$ & PFS at 6 mts: $93 \%$ & $\begin{array}{c}\mathrm{mPFS} \text { of } 20 \mathrm{mts} \text {; mDOR of } 22 \mathrm{mts} \text {; } \\
\text { OS at } 18 \mathrm{mts}: 68 \% \text {; PFS at } 18 \mathrm{mts} \text { : } \\
50 \%\end{array}$ \\
\hline $\begin{array}{l}\text { CRS, grade } 3 \text { or } \\
\text { higher, } \%\end{array}$ & $1 / 51(2 \%)$ & 7/128 (5\%) & $2 / 29(7 \%)$ & $4 / 57(7 \%)$ \\
\hline
\end{tabular}

*, should have received immunomodulatory drug (IMiD), a proteasome inhibitor (PI) and an anti-CD38 antibody. CR, complete response; sCR, stringent complete response; ORR, overall response rate; VGPR, very good partial response; PR, partial response; mPFS, median progression-free survival; mDOR, median duration of response; OS, overall survival; mts, months; CRS, cytokine release syndrome; pts, patients; MM, multiple myeloma; Cy/Flu, cyclophosphamide and fludarabine.

of a 4-1BB costimulatory domain resulted in greater T-cell persistence and antitumor activity compared to the CD28 domain (43). A clinical study comparing, anti-CD19 CAR T-cell with a CD28 co-stimulatory domain versus an antiCD19 CAR T-cell with a 4-1BB costimulatory in relapsed or refractory B-cell NHL manufactured under similar conditions, showed similar anti-tumor efficacy however, with longer persistence of the CAR T-cell with the 4-1BB co-stimulatory domain (44). After the success of secondgeneration CAR T-cell constructs in clinical trials, the development of newer constructs is ongoing. Thirdgeneration CAR T-cells consist of two costimulatory molecules. The most common co-stimulatory domains used in third-generation CAR T-cells include CD28 and 4-1BB with early trials demonstrating safety and efficacy $(45,46)$. Fourth-generation CAR T-cells contain a cytokine secreting domain in addition to the costimulatory molecules to promote an immune favorable tumor microenvironment. They are also known as T-cells redirected for universal cytokine-mediated killing (TRUCKs). This strategy is to boost T-cell anti-tumor effects with the help of several cytokines. As these cytokines may exhibit systemic toxicity, with localized delivery of the cytokines we hope to limit systemic adverse events. The studies with fourth-generation CAR T-cells are mostly preclinical and in solid tumors (47). A T-cell mediated response directed at epitopes targeted 


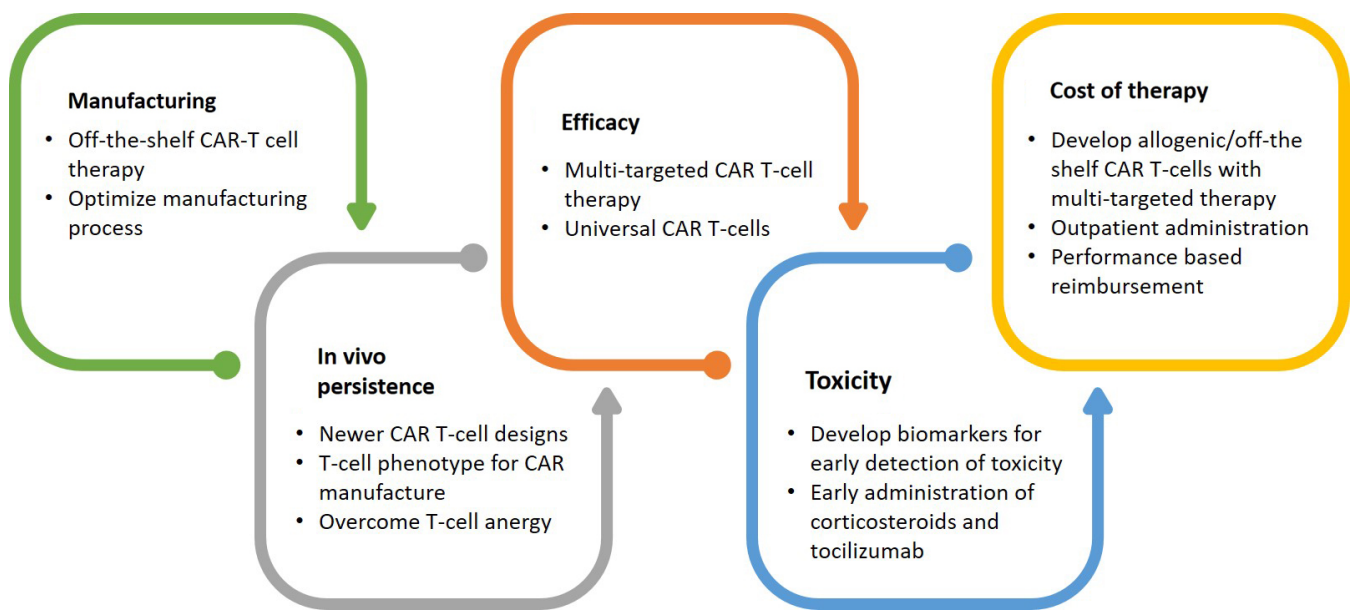

Figure 2 Current challenges and potential strategies to improve outcomes with CAR T-cell therapy.

by murine anti-CD19 scFv leads to decreased persistence of CAR-T cells (48). A newer CAR design with humanized $\mathrm{scFv}$ has shown reduced CAR T-cell antigenicity and improved efficacy in B-ALL patients who have relapsed after murine based CD19 CAR T-cell therapy (49). The hope, with these newer designs, is to allow more significant T-cell expansion and persistence.

The T-cell phenotype used for adoptive cell therapy influences the persistence and expansion of CAR T-cells. In the ZUMA-1 and JULIET trials, patients received T-cell products comprising random compositions of CD4+ and CD8+ naive and memory $\mathrm{T}$ cells. The antigenspecific CD4+ and CD8+ naive and memory $\mathrm{T}$ cells have a synergistic effect on tumor efficacy (50). These variations in T-cell composition may amount to a difference in response rates amongst these trials. Adoptive transfer of defined CD4+ and CD8+ T-cell ratios show clear benefits with synergistic effect on tumor efficacy; however, achieving a desirable proportion of CD4+ and CD8+ T-cells in lymphoid malignancies can be challenging due to prior lymphocyte toxic chemotherapy. Due to extensive cell selection, the costs and processing time increase with an overall lowered CAR T-cell product. Newer cell processing instruments such as the CliniMACS ${ }^{\circledR}$ Prodigy (Miltenyi Biotec, Inc.) systems allow the enrichment of specific subsets of $\mathrm{T}$ cells, such as CD4+, CD8+, CD25+, or CD62L+ T cells with the generation of CAR T-cell within 14 days, significantly shortening the time required (51). Lisocabtagene maraleucel in the Transcend NHL 001 trial utilized CD4+and CD8+ T-cells with a median manufacturing time of 24-days, indicating the feasibility of such an approach (52).

CAR T-cell infusion has shown to increase the expression of immune checkpoints on the tumor cells. Immune checkpoints are regulatory molecules that prevent effective activation of the immune system for antitumor efficacy.

Tumor cells overexpress PD-L1, which interacts with $\mathrm{PD}-1$ present on the T-cells leading to T-cell anergy. Such an increase in PD-1 expression has been seen in tissues samples of B-cell malignancy patients treated with CD19 CAR T-cells (53). Checkpoint inhibitors such as pembrolizumab have been used to increase CAR T-cell persistence (54). In an early phase trial (ZUMA-6), a PD-L1 inhibitor atezolizumab was used in combination with axicel (55). The trial demonstrated a manageable safety profile with a more than two-fold increase in CAR T-cell expansion compared to infusion with axi-cel alone, as in the ZUMA1 trial. Similar results were also seen with the combination of durvalumab, another PD-L1 inhibitor, and liso-cel (56). There an ongoing phase I/II trial of pembrolizumab and tisa-cel [NCT02650999]. Other approaches involve utilizing intrinsic blockade of PD-1 signaling and knockout or knockdown of the PD-1 receptor (57). Another strategy is to use surface receptors to modify the tumor microenvironment. The blockage of PD1-PDL1 axis by generation of CAR T-cell with a dominant-negative PD1 molecule on its surface has shown promising results in relapsed and refractory B-cell malignancies (58). This combinational approach of overcoming T-cell exhaustion is synergistic and shows promise. There is a concern for an increased incidence of immune-related toxicities with this approach due to the overstimulation of the CAR T-cell. 
Table 5 Comparison of various toxicity grading systems utilized in CAR T-cell therapy

\begin{tabular}{|c|c|c|c|c|}
\hline Grade 1 & $\begin{array}{l}\text { Symptoms are not life- } \\
\text { threatening and require } \\
\text { symptomatic treatment } \\
\text { only (fever, nausea, } \\
\text { fatigue, headache, } \\
\text { myalgias, malaise) }\end{array}$ & $\begin{array}{l}\text { Mild reaction: } \\
\text { - Treated with supportive care, such } \\
\text { as antipyretics, antiemetics }\end{array}$ & $\begin{array}{l}\text { - Temperature } \geq 38{ }^{\circ} \mathrm{C} \\
\text { - Grade } 1 \text { organ toxicity }{ }^{2}\end{array}$ & $\begin{array}{l}\text { Fever: temperature } \geq 38^{\circ} \mathrm{C} \\
\text { WITH } \\
\text { - Hypotension: none } \\
\text { AND/OR } \\
\text { - Hypoxia: none }\end{array}$ \\
\hline Grade 2 & $\begin{array}{l}\text { Symptoms require and } \\
\text { respond to moderate } \\
\text { intervention: } \\
\text { - Oxygen requirement } \\
<40 \% \mathrm{FiO}_{2} \mathrm{OR}\end{array}$ & $\begin{array}{l}\text { Moderate reaction: } \\
\text { - Some signs of organ dysfunction }{ }^{1} \\
\text { (grade } 2 \text { creatinine or grade } 3 \text { LFTs) } \\
\text { related to CRS and not attributable } \\
\text { to any other condition }\end{array}$ & $\begin{array}{l}\text { - Hypotension responds } \\
\text { to i.v. fluids or low-dose } \\
\text { vasopressor } \\
\text { - Hypoxia requiring } \mathrm{FiO}_{2} \\
<40 \%\end{array}$ & $\begin{array}{l}\text { Fever: temperature } \geq 38^{\circ} \mathrm{C} \\
\text { WITH } \\
\text { Hypotension: not requiring } \\
\text { vasopressors } \\
\text { AND/OR }\end{array}$ \\
\hline & $\begin{array}{l}\text { - Hypotension } \\
\text { responsive to i.v. fluids } \\
\text { or } \\
\text { - Low dose of one } \\
\text { vasopressor OR Grade } \\
2 \text { organ toxicity }{ }^{1}\end{array}$ & $\begin{array}{l}\text { - Hospitalization for management of } \\
\text { CRS-related symptoms, including } \\
\text { neutropenic fever and need for } \\
\text { i.v. therapies (not including fluid } \\
\text { resuscitation for hypotension) }\end{array}$ & - Grade 2 organ toxicity ${ }^{2}$ & $\begin{array}{l}\text { Hypoxia: requiring low-flow } \\
\text { nasal cannula or blow-by }\end{array}$ \\
\hline Grade 3 & $\begin{array}{l}\text { Symptoms require and } \\
\text { respond to aggressive } \\
\text { intervention: } \\
\text { - Oxygen requirement } \\
\geq 40 \% \mathrm{FiO}_{2} \mathrm{OR} \\
\text { - Hypotension requiring } \\
\text { high-dose or multiple } \\
\text { vasopressors OR } \\
\text { - Grade } 3 \text { organ toxicity } \\
\text { or grade } 4 \text { transaminitis }\end{array}$ & $\begin{array}{l}\text { - Hospitalization required for } \\
\text { management of symptoms related } \\
\text { to organ dysfunction }{ }^{1} \text {, including } \\
\text { grade } 4 \text { LFTs or grade } 3 \text { creatinine, } \\
\text { related to CRS and not attributable } \\
\text { to any other condition } \\
\text { - Hypotension treated with } \\
\text { multiple fluid boluses or low-dose } \\
\text { vasopressors } \\
\text { - Coagulopathy requiring fresh } \\
\text { frozen plasma, cryoprecipitate, or } \\
\text { fibrinogen concentrate } \\
\text { - Hypoxia requiring supplemental } \\
\text { oxygen (nasal cannula oxygen, } \\
\text { high-flow oxygen, CPAP, or BiPAP) }\end{array}$ & $\begin{array}{l}\text { - Hypotension needing } \\
\text { high-dose or multiple } \\
\text { vasopressors } \\
\text { - Hypoxia requiring } \mathrm{FiO}_{2} \\
\geq 40 \% \\
\text { - Grade } 3 \text { organ toxicity }{ }^{2} \text { or } \\
\text { grade } 4 \text { transaminitis }\end{array}$ & $\begin{array}{l}\text { - With or without vasopressin } \\
\text { AND/OR } \\
\text { - Hypoxia: requiring high-flow } \\
\text { nasal cannula, facemask, } \\
\text { nonrebreather mask, or } \\
\text { Venturi mask }\end{array}$ \\
\hline
\end{tabular}

Table 5 (continued) 
Table 5 (continued)

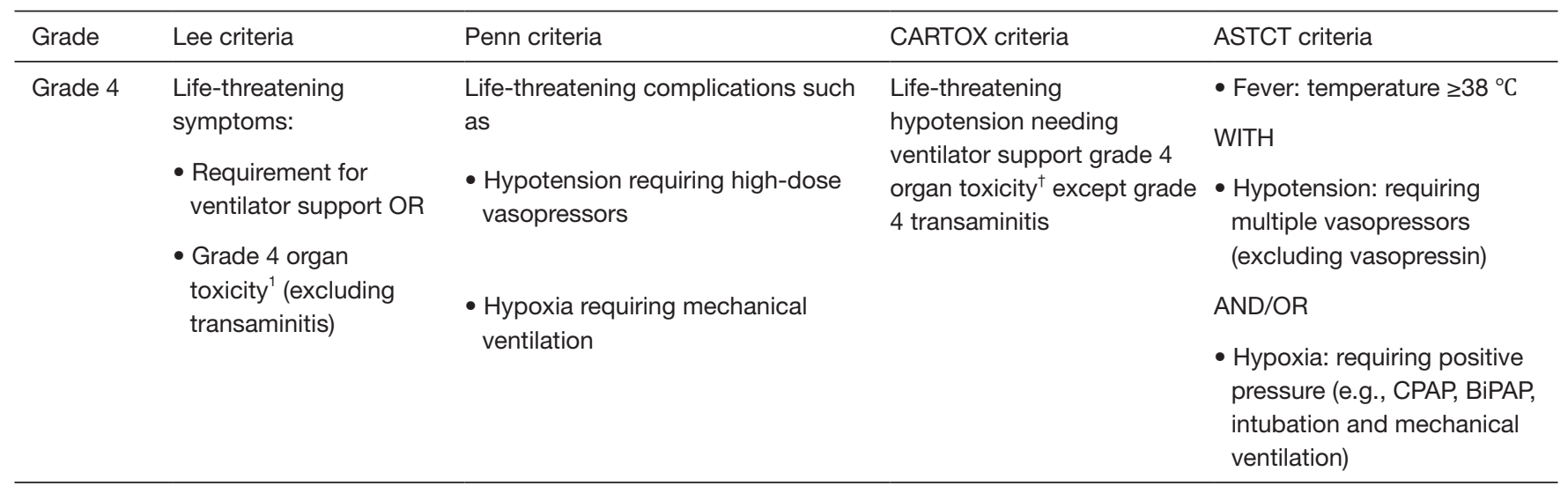

\footnotetext{
${ }^{1}$, as per CTCAE version $4.03 ;{ }^{2}$, cardiac (tachycardia, arrhythmias, heart block, low ejection fraction), respiratory (tachypnea, pleural effusion, pulmonary edema), gastrointestinal (nausea, vomiting, diarrhea), hepatic (increased serum alanine aminotransferase, aspartate aminotransferase, bilirubin level), renal (acute kidney injury, increased serum creatinine, decreased urine output), dermatologic (rash), or coagulopathy (disseminated intravascular coagulation). LFT, liver function test; CRS, cytokine release syndrome.
}

This needs to be evaluated in larger studies before future applications in the clinics.

\section{Relapses or resistance to CAR T-cell therapy}

Despite good initial response, relapses do occur after CAR T-cell therapy. Most of the relapses are due to lack of persistence of CAR T-cells as mentioned above, however a few also develop a CAR T-cell antigen negative relapse. Antigen negative relapses are seen due to antigen escape by a mutation in the antigen expressing gene. This has most extensively been studied with CD19 expressing malignancies and occurs in about one fourth of the relapses $(59,60)$. Another observed reason for antigen negative relapses is due to CAR T-cell-mediated trogocytosis. Trogocytosis is a process in which the target antigen is transferred to $\mathrm{T}$ cells, thereby decreasing target density on tumor cells and abating $\mathrm{T}$ cell activity by promoting fratricide $\mathrm{T}$ cell killing and $\mathrm{T}$ cell exhaustion (61).

\section{How can we overcome resistance to CAR T-cells?}

Targeting of a single tumor antigen such as CD19 by CAR T-cells leads to selection pressure amongst rapidly proliferating CD19+ malignant tumor cells. Subsequently, genetic mutations occur, leading to the downregulation of CD19 and, consequently, CD19 negative relapses $(59,60)$. CAR T-cells targeting two or more antigens can decrease the development of such mutations and, subsequently, antigen-negative relapses. Multi-target CAR T-cell therapy can be achieved by using bicistronic CAR T-cells, tandem CAR T-cells, pooled mixture of CAR T-cells targeting two different targets or by co-transduction of CAR T-cells with two separate gene vectors (Figure 3). Bicistronic CAR T-cells use bicistronic vectors that encode two different CARs on the same cells. A bicistronic CAR T-cell targeting CD19 and CD22 has been successfully developed and studied in early phase clinical trials in relapsed and refractory DLBCL with a manageable safety profile (62). Tandem CAR T-cells is one in which a single CAR T-cell has two different antigen-recognizing epitopes on the same receptor. Another strategy is the development of T-cells with universal CARs, which can target multiple tumor-associated antigens (TAA) simultaneously and at different concentrations.

\section{What are universal CARs, and how can they improve tumor specificity?}

Universal CARs are a type of engineered CAR T-cells with CARs designed to recognize different tumor antigens in vivo without the need for manufacturing antigenspecific CARs. They allow expanding the spectrum of antigens that can be targeted by the same CAR T-cell. Universal CARs separate the antigen-binding domain from the T-cell body, permitting the same T-cell body to target different antigens. It allows targeting multiple TAA simultaneously. Since tumor cells in different patients with the same malignancy have variable expressions of TAA, the manufacturing of these universal CARs will allow better tumor specificity. The two systems currently in 

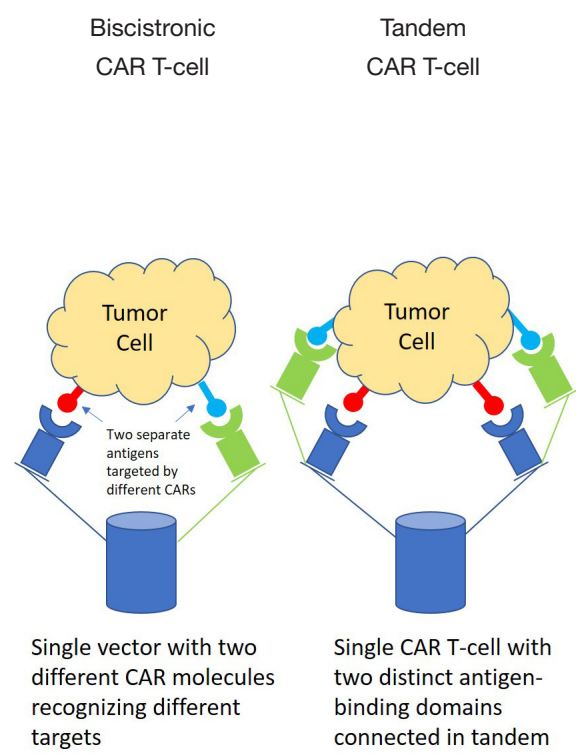

Single CAR T-cell with two distinct antigenbinding domains connected in tandem
Pooled CAR T-cell

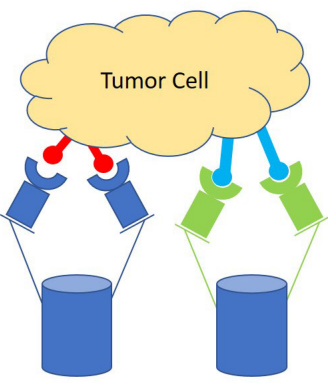

Two CAR T-cells targeting different antigens administered together

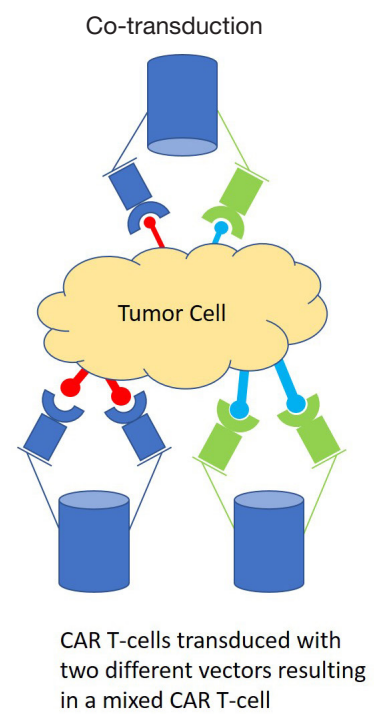

Figure 3 Multi-targeted CAR T-cell therapeutic approaches. Biscistronic CAR T-cell contain a single vector with two different antigen recognizing sites. As a result, a hybrid T-cell is formed with two receptors targeting different antigens. Tandem CAR T-cells have two antigen recognizing epitopes on the same receptor. Pooled CAR T-cells strategy consisting of infusing two separate CAR T-cell constructs which target different antigens. Co-transduction involves using two different lentiviral or retroviral vectors containing different CAR genes resulting a CAR T-cell product, which is a mixture of all possible combination. (Adapted from Majzner et al. Cancer Discovery 2018).

development include the biotin-binding immune receptor (BBIR) CAR and the split, universal and programmable (SUPRA) CAR system (63-65). Both systems use an antigen recognizing molecule and a genetically engineered T-cell that can bind to these molecules. The BBIR CAR system uses a biotinylated antigen-specific molecule, which tags tumor antigen containing tumor cells for recognition by the biotin-binding T-cell with an extracellular avidin domain (Figure 4A). The SUPRA CAR system uses an scFv fused to a cognate leucine zipper (zipFv) and a T-cell with a leucine zipper as its extracellular domain (zipCAR). The zipFV tags tumor antigens with its $\mathrm{scFv}$ and provides a binding site for the zipCAR via leucine zipper adaptor molecules (Figure 4B). Both these systems are still in their early stages of development; however, they provide a glimpse into the future of patient-specific therapy.

\section{Toxicities with CAR-T cell therapy}

Although quite promising, CAR T-cell therapy can lead to severe toxicities. Most significant among them are the cytokine release syndrome (CRS) and neurotoxicity. CRS is presumably due to activation of the immune system by proliferating CAR T-cells with the recruitment of other
T-cells. The hyperactive immune system leads to the release of pro-inflammatory cytokines such as interleukin-6 (IL-6), IL-10, interferon- $\gamma$, and granulocyte-macrophage stimulating factor (66). Clinically, CRS manifests as fever, fatigue, malaise, nausea, tachycardia, hypotension, capillary leak syndrome, and end-organ damage. The severity of CRS was graded based on various criteria in the past, but now, American Society for Transplantation and Cellular Therapy (ASTCT) recommends the use of ASTCT consensus criteria for grading of CRS (Table 5) (67). Most patients with grade 1 CRS are managed with supportive care, whereas higher grades of CRS require the administration of interleukin-6 antagonist, tocilizumab. Neurotoxicity is the second most common adverse event with CAR T-cell therapy, which is now termed as immune effector cells-associated neurotoxicity syndrome (ICANS). The pathophysiology of ICANS is less well understood. It manifests clinically as toxic encephalopathy with confusion, word-finding difficulty, and aphasia, but it can seldom progress to more severe forms with coma, seizures, motor weakness, and cerebral edema. The frequency of severe CRS and ICANS ranges from $10 \%$ to $30 \%$ for different CAR T-cell constructs. It continues to be one of the significant limitations requiring inpatient monitoring 


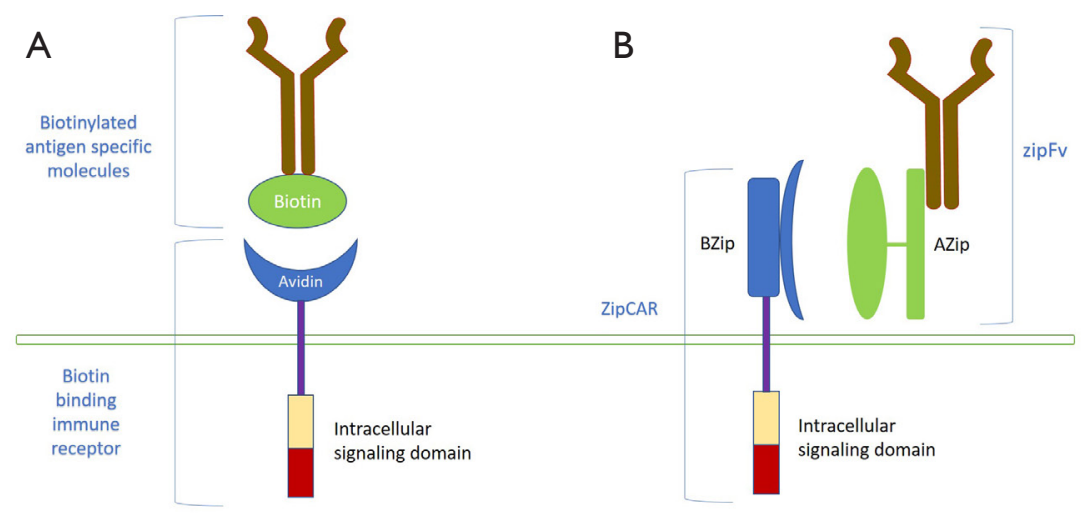

Figure 4 Structure of the BBIR CAR, which consists of two separate components. Antigen specific biotinylated molecules, which can couple with biotin binding immune receptor. (Adapted from Urbanska K, et al. Cancer Res. 2012); (B) Structure of SUPRA CAR. The antigen recognizing system here is fused to a cognate leucine zipper (zipFv) while the T-cell has a leucine zipper as its extracellular domain (zipCAR). (Adapted from Cho et al. Cell 2018).

(Table 1). In addition to CRS and neurotoxicity, offtarget effects are observed, resulting in B-cell aplasia and hypogammaglobulinemia. B-cell aplasia leads to long term increased risk of infection and dependence on intravenous gammaglobulin infusions.

The risk of severe CRS and ICANS with CAR-T cell therapy is high. Intensive inpatient monitoring is required with the availability of neurology consultants and the intensive care unit. Currently, the IL-6 antagonist, tocilizumab, is the most widely used medication in the event of severe CRS and is required to be available for emergent administration. These requirements limit the use of CAR T-cell therapy to specialized medical centers. Outpatient administration of liso-cel was studied due to late-onset and lower incidence of toxicities (68). In this study, there were no deaths, and the efficacy was comparable to the general population who received liso-cel therapy inpatient. However, patients were highly selected with strict requirements for monitoring and may not apply to the general population who receive their care away from an academic/specialized tertiary center.

Not all patients develop life threatening CRS with CAR T-cell therapy. Therefore, predictive biomarkers for early identification of patients who might develop grade 3 or higher CRS is required. The predictive utility of biomarkers, such as high serum levels of c-reactive protein (CRP), ferritin, IL-6, IL-10, IFN- $\gamma$, and IL-15 vary and depend upon the type of CAR T-cell product used (15) $(48,69-71)$. We are yet to successfully identify a biomarker with high predictive capacity. Another strategy is the early administration of corticosteroids and the IL-6 antagonist, tocilizumab, to reduce to the severity of CRS and ICANS. This was studied in cohort 4 of the ZUMA-1 trial (72). In this early intervention cohort, only two percent of patients experienced grade $\geq 3$ CRS, and $17 \%$ experienced grade $\geq 3$ neurological events compared to $13 \%$ and $28 \%$, respectively, in the non-early intervention group. The overall response rate and duration of response were similar between the groups suggesting the possibility of early intervention without compromising efficacy. Our experience with early recognition and management of CRS and ICANS is improving with a higher proportion of patients treated with adoptive T-cell therapy. A composite approach of outpatient therapy, early identification of patients with risk of severe adverse events, and early administration of corticosteroids and tocilizumab may allow CAR T-cell therapy to be safely administered in community hospitals. It will subsequently expand access to CAR T-cell therapy to the general population.

\section{Costs with CAR T-cell therapy}

In the United States, single treatment with Yescarta ${ }^{\circledR}$ (axi-cel) costs around USD 373,000, whereas Kymriah ${ }^{\circledR}$ (tisa-cel) costs about USD 475,000 per patient. The individualized nature of therapy, complexity, and laborintensive manufacturing are few reasons provided by the manufacturers to explain such expensive price tags. These costs do not include hospital stay, medications toxicity management, and supportive care, which could amount 
to a total of around USD 750,000 to $1,000,000$. The reimbursement of CAR T-cell therapy by payers may not include coverage of the overhead costs incurred by the hospital. Therefore, very few centers in the United States are currently able to provide CAR T-cell therapy for patients. If CAR T-cell therapy moves to the second line setting in DLBCL and gets approved in other lymphoid malignancies, the total healthcare costs would likely be much higher. The hope is, in the future, the combination of "off-the shelf" CAR T-cells with universal CAR T-cells will significantly lower the cost while improving its efficacy.

\section{Future directions}

There is no doubt that the advent of CAR-T cell therapies has revolutionized the care of patients with various lymphoid neoplasms. The median overall survival in the ZUMA-1 study of relapsed/refractory DLBCL after failure of at least 2 lines of therapy was not reached at 28-month follow-up, which is an unprecedented outcome in an otherwise uniformly fatal situation. Given these results, CAR T-cell therapy is now being evaluated in comparison with autologous stem cell transplant approach among DLBCL patients who relapse after first line therapy (ZUMA-7 trial; NCT03391466). It is likely that CAR T-cell therapy will see more approvals in the near future, thereby leading to increasing number of eligible patients. However, given the intensive monitoring and personnel training required, the administration of CAR T-cell therapy is limited to select tertiary centers in the US and the world. In the long-term follow-up of ZUMA-1 trial, approximately $50 \%$ of patients who initially responded lost their response at longer follow-up. Similarly, the median overall survival in JULIET study was 11.5 months, but was not reached at median follow-up of 19 months among patients who achieved a CR. These findings underscore the need to conduct further research for better patient selection to optimize CAR T-cell treatments. As CAR T-cell therapy gets approved for more indications, payer reimbursements will become unsustainable at the prevailing costs. Although the initial high cost can be attributed to research and development expenditures, the cost of subsequent expansion of CAR T-cell products may be lower and prices may need to be re-negotiated down the road. As future research is being conducted into improving the CAR T-cell treatments, a major focus should be the mitigation of physical and financial toxicities, so most eligible patients can have easy access to therapy at a center near them.

\section{Acknowledgments}

Funding: None.

\section{Footnote}

Provenance and Peer Review: This article was commissioned by the Guest Editors (Umang Swami and Mohammed M. Milhem) for the series "Cancer Immunotherapy: Recent Advances and Challenges" published in Annals of Translational Medicine. The article has undergone external peer review.

Peer Review File: Available at http://dx.doi.org/10.21037/ atm-20-5546

Conflicts of Interest: All authors have completed the ICMJE uniform disclosure form (available at http:// dx.doi.org/10.21037/atm-20-5546). The series "Cancer Immunotherapy: Recent Advances and Challenges" was commissioned by the editorial office without any funding or sponsorship. Dr. SMA reports that he receives research funding (to his institution for clinical trials) from Bristol Myers Squibb, Affimed, Seattle Genetics, Regeneron, AI Therapeutics, Trillium and ADC Therapeutics. Dr. AM reports that he receives research funding from Incyte, Takeda, Fortyseven Inc./Gilead, Juno pharmaceuticals/ Bristol Myers Squibb, Celgene/Bristol Myers Squibb, Oncotartis, Innate pharmaceuticals, Seattle Genetics, TG Therapeutics, Affimed, Merck, Kite/Gilead, RocheGenentech, ADC therapeutics, Miragen, Rhizen Pharmaceuticals, and consultancy/speaker bureau fees from Gilead, Astra Zeneca, Pharmacyclics, Seattle Genetics, Incyte, Morphosys/Incyte, TG Therapeutics, Carevive, Kyowa Kirin, Rigel pharmaceuticals. The authors have no other conflicts of interest to declare.

Ethical Statement: The authors are accountable for all aspects of the work in ensuring that questions related to the accuracy or integrity of any part of the work are appropriately investigated and resolved.

Open Access Statement: This is an Open Access article distributed in accordance with the Creative Commons Attribution-NonCommercial-NoDerivs 4.0 International License (CC BY-NC-ND 4.0), which permits the noncommercial replication and distribution of the article with the strict proviso that no changes or edits are made and the 
original work is properly cited (including links to both the formal publication through the relevant DOI and the license). See: https://creativecommons.org/licenses/by-nc-nd/4.0/.

\section{References}

1. Stancovski I, Schindler DG, Waks T, et al. Targeting of T lymphocytes to Neu/HER2-expressing cells using chimeric single chain Fv receptors. J Immunol 1993;151:6577.

2. Hombach A, Heuser C, Sircar R, et al. T cell targeting of TAG72+ tumor cells by a chimeric receptor with antibody-like specificity for a carbohydrate epitope. Gastroenterology 1997;113:1163-70.

3. Moritz D, Wels W, Mattern J, et al. Cytotoxic T lymphocytes with a grafted recognition specificity for ERBB2-expressing tumor cells. Proc Natl Acad Sci 1994;91:4318.

4. Moritz D, Groner B. A spacer region between the single chain antibody-and the $\mathrm{CD} 3$ zeta-chain domain of chimeric $\mathrm{T}$ cell receptor components is required for efficient ligand binding and signaling activity. Gene Ther 1995;2:539-46.

5. Crump M, Neelapu SS, Farooq U, et al. Outcomes in refractory diffuse large B-cell lymphoma: results from the international SCHOLAR-1 study. Blood 2017;130:1800-8.

6. Casulo C, Byrtek M, Dawson KL, et al. Early Relapse of Follicular Lymphoma After Rituximab Plus Cyclophosphamide, Doxorubicin, Vincristine, and Prednisone Defines Patients at High Risk for Death: An Analysis From the National LymphoCare Study. J Clin Oncol 2015;33:2516-22.

7. Kumar SK, Dimopoulos MA, Kastritis E, et al. Natural history of relapsed myeloma, refractory to immunomodulatory drugs and proteasome inhibitors: a multicenter IMWG study. Leukemia 2017;31:2443-8.

8. Martin P, Maddocks K, Leonard JP, et al. Postibrutinib outcomes in patients with mantle cell lymphoma. Blood 2016;127:1559-63.

9. Pule MA, Savoldo B, Myers GD, et al. Virus-specific T cells engineered to coexpress tumor-specific receptors: persistence and antitumor activity in individuals with neuroblastoma. Nat Med 2008;14:1264-70.

10. Kershaw MH, Westwood JA, Parker LL, et al. A Phase I Study on Adoptive Immunotherapy Using GeneModified T Cells for Ovarian Cancer. Clin Cancer Res 2006;12:6106.

11. Lamers CHJ, Langeveld SCL, Groot-van Ruijven CM, et al. Gene-modified $\mathrm{T}$ cells for adoptive immunotherapy of renal cell cancer maintain transgene-specific immune functions in vivo. Cancer Immunol Immunother 2007; 56:1875-83.

12. Tedder TF, Inaoki M, Sato S. The CD19-CD21 Complex Regulates Signal Transduction Thresholds Governing Humoral Immunity and Autoimmunity. Immunity 1997;6:107-18.

13. Anderson KC, Bates MP, Slaughenhoupt BL, et al. Expression of human B cell-associated antigens on leukemias and lymphomas: a model of human B cell differentiation. Blood 1984;63:1424-33.

14. Porter DL, Levine BL, Kalos M, et al. Chimeric Antigen Receptor-Modified T Cells in Chronic Lymphoid Leukemia. N Engl J Med 2011;365:725-33.

15. Porter DL, Hwang WT, Frey NV, et al. Chimeric antigen receptor $\mathrm{T}$ cells persist and induce sustained remissions in relapsed refractory chronic lymphocytic leukemia. Sci Transl Med 2015;7:303ra139.

16. Locke FL, Ghobadi A, Jacobson CA, et al. Long-term safety and activity of axicabtagene ciloleucel in refractory large B-cell lymphoma (ZUMA-1): a single-arm, multicentre, phase 1-2 trial. Lancet Oncol 2019;20:31-42.

17. Schuster SJ, Bishop MR, Tam CS, et al. Long-Term Follow-up of Tisagenlecleucel in Adult Patients with Relapsed or Refractory Diffuse Large B-Cell Lymphoma: Updated Analysis of Juliet Study. Biology of Blood and Marrow Transplantation 2019;25:S20-1.

18. Abramson JS, Palomba ML, Arnason JE, et al. Lisocabtagene maraleucel (liso-cel) treatment of patients (pts) with relapsed/refractory (R/R) B-cell non-Hodgkin lymphoma (NHL) and secondary CNS lymphoma: Initial results from TRANSCEND NHL 001. J Clin Oncol 2019;37:7515.

19. Wang M, Munoz J, Goy A, et al. KTE-X19 CAR T-Cell Therapy in Relapsed or Refractory Mantle-Cell Lymphoma. N Engl J Med 2020;382:1331-42.

20. Jacobson CA, Chavez JC, Sehgal AR, et al. Interim analysis of ZUMA-5: A phase II study of axicabtagene ciloleucel (axi-cel) in patients (pts) with relapsed/refractory indolent non-Hodgkin lymphoma (R/R iNHL). J Clin Oncol 2020;38:8008.

21. Siddiqi T, Soumerai JD, Dorritie KA, et al. Rapid Undetectable MRD (uMRD) Responses in Patients with Relapsed/Refractory (R/R) Chronic Lymphocytic Leukemia/Small Lymphocytic Lymphoma (CLL/SLL) Treated with Lisocabtagene Maraleucel (liso-cel), a CD19Directed CAR T Cell Product: Updated Results from Transcend CLL 004, a Phase 1/2 Study Including Patients 
with High-Risk Disease Previously Treated with Ibrutinib. Blood 2019;134:503.

22. Gill SI, Vides V, Frey NV, et al. Prospective Clinical Trial of Anti-CD19 CAR T Cells in Combination with Ibrutinib for the Treatment of Chronic Lymphocytic Leukemia Shows a High Response Rate. Blood 2018;132:298.

23. Till BG, Jensen MC, Wang J, et al. CD20-specific adoptive immunotherapy for lymphoma using a chimeric antigen receptor with both CD28 and 4-1BB domains: pilot clinical trial results. Blood 2012;119:3940-50.

24. Shah NN, Johnson BD, Schneider D, et al. Bispecific anti-CD20, anti-CD19 CAR T cells for relapsed B cell malignancies: a phase 1 dose escalation and expansion trial. Nat Med 2020;26:1569-75.

25. Falini B, Pileri S, Pizzolo G, et al. CD30 (Ki-1) molecule: a new cytokine receptor of the tumor necrosis factor receptor superfamily as a tool for diagnosis and immunotherapy. Blood 1995;85:1-14.

26. Adcetris (Brentuximab Vedotin) [package insert]. U.S. Food and Drug Administration Revised October 2019, Accessed July 2020.

27. Wang CM, Wu ZQ, Wang Y, et al. Autologous T Cells Expressing CD30 Chimeric Antigen Receptors for Relapsed or Refractory Hodgkin Lymphoma: An OpenLabel Phase I Trial. Clin Cancer Res 2017;23:1156.

28. Wang D, Zeng C, Xu B, et al. Anti-CD30 chimeric antigen receptor $\mathrm{T}$ cell therapy for relapsed/refractory CD30+ lymphoma patients. Blood Cancer J 2020;10:8.

29. Ramos CA, Torrano V, Bilgi M, et al. CD30-chimeric antigen receptor (CAR) $\mathrm{T}$ cells for therapy of Hodgkin lymphoma (HL). Hematol Oncol 2019;37:168.

30. Ramos CA, Ballard B, Zhang H, et al. Clinical and immunological responses after CD30-specific chimeric antigen receptor-redirected lymphocytes. J Clin Invest 2017;127:3462-71.

31. Berdeja JG, Madduri D, Usmani SZ, et al. Update of CARTITUDE-1: A phase Ib/II study of JNJ-4528, a B-cell maturation antigen (BCMA)-directed CAR-T-cell therapy, in relapsed/refractory multiple myeloma. J Clin Oncol 2020;38:8505.

32. Mailankody S, Jakubowiak AJ, Htut M, et al. Orvacabtagene autoleucel (orva-cel), a B-cell maturation antigen (BCMA)-directed CAR T cell therapy for patients (pts) with relapsed/refractory multiple myeloma (RRMM): update of the phase 1/2 EVOLVE study (NCT03430011). J Clin Oncol 2020;38:8504.

33. Munshi NC, Anderson JLD, Shah N, et al. Idecabtagene vicleucel (ide-cel; bb2121), a BCMA-targeted CAR T-cell therapy, in patients with relapsed and refractory multiple myeloma (RRMM): Initial KarMMa results. J Clin Oncol 2020;38:8503.

34. Wang BY, Zhao WH, Liu J, et al. Long-Term Followup of a Phase 1, First-in-Human Open-Label Study of LCAR-B38M, a Structurally Differentiated Chimeric Antigen Receptor T (CAR-T) Cell Therapy Targeting B-Cell Maturation Antigen (BCMA), in Patients (pts) with Relapsed/Refractory Multiple Myeloma (RRMM). Blood 2019;134:579.

35. Guo B, Chen M, Han Q, et al. CD138-directed adoptive immunotherapy of chimeric antigen receptor (CAR)modified $\mathrm{T}$ cells for multiple myeloma. J Cell Immuno 2016;2:28-35.

36. Jain MD, Jacobs MT, Nastoupil LJ, et al. Characteristics and Outcomes of Patients Receiving Bridging Therapy While Awaiting Manufacture of Standard of Care Axicabtagene Ciloleucel CD19 Chimeric Antigen Receptor (CAR) T-Cell Therapy for Relapsed/Refractory Large B-Cell Lymphoma: Results from the US Lymphoma CAR-T Consortium. Blood 2019;134:245.

37. Liu E, Marin D, Banerjee P, et al. Use of CAR-Transduced Natural Killer Cells in CD19-Positive Lymphoid Tumors. N Engl J Med 2020;382:545-53.

38. Benjamin R, Graham C, Yallop D, et al. Preliminary Data on Safety, Cellular Kinetics and Anti-Leukemic Activity of UCART19, an Allogeneic Anti-CD19 CAR T-Cell Product, in a Pool of Adult and Pediatric Patients with High-Risk CD19+ Relapsed/Refractory B-Cell Acute Lymphoblastic Leukemia. Blood 2018;132:896.

39. Qasim W, Zhan H, Samarasinghe S, et al. Molecular remission of infant B-ALL after infusion of universal TALEN gene-edited CAR T cells. Sci Transl Med 2017;9:eaaj2013.

40. Neelapu SS, Munoz J, Locke FL, et al. First-in-human data of ALLO-501 and ALLO-647 in relapsed/refractory large B-cell or follicular lymphoma (R/R LBCL/FL): ALPHA study. J Clin Oncol 2020;38:8002.

41. Maus MV, Grupp SA, Porter DL, et al. Antibodymodified T cells: CARs take the front seat for hematologic malignancies. Blood 2014;123:2625-35.

42. Kawalekar OU, O'Connor RS, Fraietta JA, et al. Distinct Signaling of Coreceptors Regulates Specific Metabolism Pathways and Impacts Memory Development in CAR T Cells. Immunity 2016;44:380-90.

43. Zhao Z, Condomines M, van der Stegen Sjoukje JC, et al. Structural Design of Engineered Costimulation Determines Tumor Rejection Kinetics and Persistence of 
CAR T Cells. Cancer Cell 2015;28:415-28.

44. Ying Z, He T, Wang X, et al. Parallel Comparison of 4-1BB or CD28 Co-stimulated CD19-Targeted CAR-T Cells for B Cell Non-Hodgkin's Lymphoma. Mol Ther Oncolytics 2019;15:60-8.

45. Schubert ML, Schmitt A, Neuber B, et al. ThirdGeneration CAR T Cells Targeting CD19 Are Associated with an Excellent Safety Profile and Might Improve Persistence of CAR T Cells in Treated Patients. Blood 2019;134:51.

46. Tang XY, Sun Y, Zhang A, et al. Third-generation CD28/4-1BB chimeric antigen receptor $T$ cells for chemotherapy relapsed or refractory acute lymphoblastic leukaemia: a non-randomised, open-label phase I trial protocol. BMJ Open 2016;6:e013904.

47. Chmielewski M, Abken H. CAR T Cells Releasing IL-18 Convert to T-Bethigh FoxO1low Effectors that Exhibit Augmented Activity against Advanced Solid Tumors. Cell Rep 2017;21:3205-19.

48. Turtle CJ, Hanafi LA, Berger C, et al. CD19 CAR-T cells of defined CD4+:CD8+ composition in adult B cell ALL patients. J Clin Invest 2016;126:2123-38.

49. Zhao Y, Liu Z, Wang X, et al. Treatment with Humanized Selective CD19CAR-T Cells Shows Efficacy in Highly Treated B-ALL Patients Who Have Relapsed after Receiving Murine-Based CD19CAR-T Therapies. Clin Cancer Res 2019;25:5595-607.

50. Sommermeyer D, Hudecek M, Kosasih PL, et al. Chimeric antigen receptor-modified $\mathrm{T}$ cells derived from defined CD8+ and CD4+ subsets confer superior antitumor reactivity in vivo. Leukemia 2016;30:492-500.

51. Zhu F, Shah NN, Xu H, et al. CAR-T Cell Production Using the Clinimacs® Prodigy System. Blood 2016;128:5724.

52. Teoh J, Johnstone TG, Christin B, et al. Lisocabtagene Maraleucel (liso-cel) Manufacturing Process Control and Robustness across CD19+ Hematological Malignancies. Blood 2019;134:593.

53. Kochenderfer JN, Dudley ME, Kassim SH, et al. Chemotherapy-Refractory Diffuse Large B-Cell Lymphoma and Indolent B-Cell Malignancies Can Be Effectively Treated With Autologous T Cells Expressing an Anti-CD19 Chimeric Antigen Receptor. J Clin Oncol 2015;33:540-9.

54. Maude SL, Hucks GE, Seif AE, et al. The effect of pembrolizumab in combination with CD19-targeted chimeric antigen receptor (CAR) $\mathrm{T}$ cells in relapsed acute lymphoblastic leukemia (ALL). J Clin Oncol 2017;35:103.
55. Jacobson CA, Locke FL, Miklos DB, et al. End of Phase 1 Results from Zuma-6: Axicabtagene Ciloleucel (Axi-Cel) in Combination with Atezolizumab for the Treatment of Patients with Refractory Diffuse Large B Cell Lymphoma. Biol Blood Marrow Transplant 2019;25:S173.

56. Siddiqi T, Abramson JS, Lee HJ, et al. Safety of Lisocabtagene Maraleucel given with durvalumab in patients with relapsed/refractory aggressive b-cell non Hodgkin lymphoma: first results from the platform study. Hematol Oncol 2019;37:171-2.

57. Cherkassky L, Morello A, Villena-Vargas J, et al. Human CAR T cells with cell-intrinsic PD-1 checkpoint blockade resist tumor-mediated inhibition. J Clin Invest 2016;126:3130-44.

58. Pu C, Huang L, Su Y, et al. Dominant negative PD1 armored CART cells to induce remission in relapsed or refractory non-Hodgkin lymphoma (NHL) patients. J Clin Oncol 2020;38:e15028.

59. Orlando EJ, Han X, Tribouley C, et al. Genetic mechanisms of target antigen loss in CAR19 therapy of acute lymphoblastic leukemia. Nat Med 2018;24:1504-6.

60. Shalabi H, Kraft IL, Wang HW, et al. Sequential loss of tumor surface antigens following chimeric antigen receptor T-cell therapies in diffuse large B-cell lymphoma. Haematologica 2018;103:e215.

61. Hamieh M, Dobrin A, Cabriolu A, et al. CAR T cell trogocytosis and cooperative killing regulate tumour antigen escape. Nature 2019;568:112-6.

62. Ardeshna KM, Marzolini MAV, Norman J, et al. Phase 1/2 Study of AUTO3 the First Bicistronic Chimeric Antigen Receptor (CAR) Targeting CD19 and CD22 Followed By an Anti-PD1 in Patients with Relapsed/Refractory (r/r) Diffuse Large B Cell Lymphoma (DLBCL): Results of Cohort 1 and 2 of the Alexander Study. Blood 2019;134:246.

63. Lohmueller JJ, Ham JD, Kvorjak M, et al. mSA2 affinityenhanced biotin-binding CAR T cells for universal tumor targeting. Oncoimmunology 2017;7:e1368604.

64. Urbanska K, Lanitis E, Poussin M, et al. A universal strategy for adoptive immunotherapy of cancer through use of a novel T-cell antigen receptor. Cancer Res 2012;72:1844-52.

65. Cho JH, Collins JJ, Wong WW. Universal Chimeric Antigen Receptors for Multiplexed and Logical Control of T Cell Responses. Cell 2018;173:1426-38.e11.

66. Neelapu SS, Tummala S, Kebriaei P, et al. Chimeric antigen receptor T-cell therapy - assessment and management of toxicities. Nat Rev Clin Oncol 
2018;15:47-62.

67. Lee DW, Santomasso BD, Locke FL, et al. ASTCT Consensus Grading for Cytokine Release Syndrome and Neurologic Toxicity Associated with Immune Effector Cells. Biol Blood Marrow Transplant 2019;25:625-38.

68. Bachier CR, Palomba ML, Abramson JS, et al. Outpatient Treatment with Lisocabtagene Maraleucel (liso-cel) in Three Ongoing Clinical Studies in Relapsed/Refractory (R/R) B Cell Non-Hodgkin Lymphoma (NHL), Including Second-Line Transplant Ineligible Patients: Transcend NHL 001, Outreach, and PILOT. Blood 2019;134:2868.

69. Maude SL, Frey N, Shaw PA, et al. Chimeric Antigen Receptor T Cells for Sustained Remissions in Leukemia.
N Engl J Med 2014;371:1507-17.

70. Lee DW, Kochenderfer JN, Stetler-Stevenson M, et al. T cells expressing CD19 chimeric antigen receptors for acute lymphoblastic leukaemia in children and young adults: a phase 1 dose-escalation trial. Lancet 2015;385:517-28.

71. Teachey DT, Lacey SF, Shaw PA, et al. Identification of Predictive Biomarkers for Cytokine Release Syndrome after Chimeric Antigen Receptor T-cell Therapy for Acute Lymphoblastic Leukemia. Cancer Discov 2016;6:664.

72. Topp M, Van Meerten T, Houot R, et al. Earlier Steroid Use with Axicabtagene Ciloleucel (Axi-Cel) in Patients with Relapsed/Refractory Large B Cell Lymphoma. Blood 2019;134:243.

Cite this article as: Narkhede M, Mehta A, Ansell SM, Goyal G. CAR T-cell therapy in mature lymphoid malignancies: clinical opportunities and challenges. Ann Transl Med 2021;9(12):1036. doi: $10.21037 / \mathrm{atm}-20-5546$ 